\title{
Determinants Factors Affecting Stunting In Children 2-5 Years In The Working Area Of Tajinan Public Health Center
}

\author{
Rifzul Maulina \\ 1) Midwifery Professional Education, ITSK Dr Soepraoen Hospital
}

\begin{tabular}{ll}
\hline \multirow{2}{*}{$\begin{array}{l}\text { Keyword: } \\
\text { Environmental }\end{array}$} & A b s tract \\
sanitation; & Background: Malang Regency is included in the 100 priority districts for \\
Infectious & The research was to analyze risk factors related to child, mother, and \\
disease; & environmental factors for stunting under five years old. Method : The study used \\
Stunting, & a case-control design population was all children aged 2 to 5 years at the Tajinan \\
& Public Health Center for six months in 2018. The case sample was 75 stunting \\
& toddlers and the control was 75 toddlers well-nourished. Data was collected by \\
& interview and measurement (anthropometry). Data was analyzed by chi square \\
& test and multiple logistic regression. Result : $80 \%$ of stunted children had \\
& infectious diseases, a history of length of birth <48 centimeters and low birth \\
& weight was $72 \%$ and $10 \%$, a history of breastfeeding and complementary foods \\
& (59\%). The risk factors for stunting were a history of low birth weight, a history \\
& of infectious diseases, maternal education, environment sanitation, and family \\
& income. Conclusion : The most influential factors are history of infectious \\
& diseases and environment sanitation. It is necessary to increase family \\
& empowerment related to the prevention of infectious diseases through improving \\
& dietary and health care patterns and improving environment sanitation.
\end{tabular}

*Corresponding author

Email: rifzulmaulina3@gmail.com 


\section{BACKGROUND}

Stunting is one of the problems that hinders human development globally. Currently, around 162 million children under the age of five are stunted. If this trend continues, it is projected that by 2025 there will be 127 million children under five years of age who will be stunted. ${ }^{1}$ According to the United Nations Children's Emergency Fund (UNICEF) more than half of children are stunted or $56 \%$ live in Asia and more than a third or $37 \%$ live in Africa. ${ }^{1}$

Indonesia is a country with a high number of stunting, namely there are 32 provinces out of 34 provinces whose numbers are above $20 \%$ base on the stunting limit from WHO.Based on data from Riskesdas (2018), the stunting rate in Indonesia for toddlers reaches $30.8 \%$, consisting of $11.5 \%$ severe stunting and $19.3 \%$ middle stunting. The stunting rate in Indonesia decreased when compared to the 2013 Riskesdas data, which reached $37.2 \%$, consisting of $18 \%$ severe stunting and $19.2 \%$ middle stunting under five. ${ }^{2}$

According to the results of Riskesdas (2018), East Java is one of the provinces that has a high prevalence of stunting. The number of children under five with stunting in East Java in 2018 reached $25.2 \%$. Malang Regency is included in the 100 priority districts for stunting with a stunting rate of $20 \%$, which is spread across 6 priority villages. ${ }^{3}$ Based on data from the District Health Office. In Malang in 2017, the prevalence of stunting in under-five was 30,323 under five from a total of 154,188 toddlers, while for the Tajinan Public Health Center had 3,443 children under five with 607 short children and 322 very short toddlers so that the stunting cases were 929 under-five. (4) Preliminary study data dated March 12, 2019 in Malang Regency, in the working area of the Tajinan Public Health Center, to be precise in Jambearjo Village, there were 145 children under five who were stunted, while at the Wagir Health Center, there were 136 children under five who were stunted.

The World Health Organization (WHO) states the resolution of global targets on maternal and child nutrition as a priority. Its main target is to reduce stunting in children by $40 \%$ globally or a $3.9 \%$ reduction annually between 2012 and 2025. ${ }^{10}$ The 2015-2019 National MediumTerm Development Plan states that there are four priority health development programs in Indonesia, one of which is the reduction in the prevalence of stunting.

According to WHO, prevention efforts in stunting can be started in adolescence. Young women can begin to be given knowledge and understanding of the importance of fulfilling nutrition as a teenager. Fulfillment of nutrition during adolescence can prevent malnutrition during pregnancy. Adequate nutrition during pregnancy can prevent stunted growth in the fetus. ${ }^{11}$

In addition, stunting prevention is also focused on the first 1,000 days of life (HPK), namely pregnant women, nursing mothers, children 0-23 months. The 1,000 HPK period is an effective period in preventing stunting because it is a period that determines the quality of life. At 1,000 HPK children will experience a "Golden Period" in which the child's growth will be rapid. Therefore, in this period, nutritional coverage must be fulfilled starting from 270 days during pregnancy and the first 730 days after the baby is born. ${ }^{12}$ However, according to $\mathrm{WHO}$, prevention of stunting does not only start at 1,000 HPK but begins in adolescence by improving nutrition during pregnancy. teenager. $^{11}$

Prevention carried out in pregnant women can be done by improving the nutrition of pregnant women. Nutritional improvement that can be done during pregnancy is by giving blood plus tablets at least 90 tablets during pregnancy. In addition, mothers who experience Chronic Energy Deficiency (CED) need to get 
additional food to improve the nutrition of these pregnant women. 13

Based on research studies, it is known the factors that cause stunting. The factors that cause stunting from the mother are the mother's education level and the mother's height. Factors that cause stunting in infants are history of infectious disease, history of birth weight and birth length, history of immunization and history of exclusive breastfeeding. The environmental factors are family income, environmental sanitation and health services. With the knowledge of these facts, it will be further researched on the Risk Factors that Affect the Incidence of Stunting in Toddlers 2-5 Years in the Work Area of Tajinan Public Health Center

\section{RESEARCH METHODOLOGY}

This observational study used a casecontrol design to determine the factors that influence stunting in toddlers and to determine the amount of risk (odds ratio) of each factor.12 This study was conducted for 6 (six) months (February-July 2018) in the work area of Tajinan Public Health Center, Malang Regency. The population was all children aged two to 5 years (toddlers), as sample cases were 75 children with short status (stunting), while the control sample was normal toddlers closest to the case as many as 75 children with the same age. Respondents were mothers of cases and controls under five.

The case sample was taken by looking at the data on children under five who were stunted from seven villages in the Tajinan Public Health Center, while the control sample was the case's closest neighbors. If there is more than one control sample candidate, it is carried out randomly. Data obtained through interviews using a structure questionnaire. Child factors include history of birth weight and length, breastfeeding, and complementary foods of breastmilk, infectious diseases, health services and immunization. Maternal factors include maternal education and maternal height. Family environmental factors include environment sanitation, family income and health services.

The environment sanitation variable consists of several questions, then the normality test is carried out from the total score to be categorized into good and bad and the questions some from adopt other research and some from develop by researches by self. The questionnaire before it was used was carried out by testing the questionnaire on 30 mothers who had toddlers in Pandanrejo Village, Wagir Health Center area with characteristics similar to the research location, namely there were many stunting toddlers.

Breastfeeding and complementary breastfeeding are measured from the history of giving breastmilk and complementary breastfeeding from birth to the time of carrying out the study consisting of several questions about exclusive breastfeeding, age of administration, types and stages of complementary foods (complementary breastfeeding) then from the total score a normality test is carried out for categorized into good and less good. Infectious disease is a condition when a toddler is measured to have a disturbance due to the occurrence of acute respiratory infections (ARI), diarrhea, or measles during the study based on a doctor's diagnosis.

Health services and immunization are measured from the completeness of basic immunizations, namely the number of types of immunizations that have been received by toddlers according to their age and health condition. Mother's knowledge is measured by the mother's ability to correctly answer questions related to stunting, including its causes and consequences. Environmental sanitation is based on the use of waste disposal facilities and drinking water in accordance with health standards. 
Data analysis included univariate, bivariate and multivariate analyzes. Univariate analysis by performing a frequency distribution test. Bivariate analysis was used to determine the extent to which the relationship between the factors suspected of having a relationship with stunting was carried out by using the chi square test with a significance level ( $p$ value $=0.05$ ) and a confidence interval (CI) of $95 \%$. To see the most dominant risk factors, a multivariate multiple logistic regression analysis was carried out on the bivariate analysis result variables which had a $\mathrm{p}$ value $<0.25$.

\section{RESULTS}

Based on the univariate analysis by the distribution of the independent variables in the case and control groups, In case group it is known from child factors, it was found that the percentage of cases had a history of low birth weight (LBW), had a long history of low length of birth less than 48 centimeters, had a history of not good breastfeeding. and supplementary food of breast milk often suffer from infectious diseases, lack of good health. Maternal factors are known to lack knowledge in the case group.

The percentage of environmental factors in more cases is the height of the father and mother is below standard, the basic education of the father and mother, low family income, and poor environmental sanitation, which is proven to be associated with the occurrence of stunting in children under five. The complete bivariate analysis results can be seen in Table 1 below.

Based on Table 1, the results of the bivariate analysis of the relationship between child factors and stunting showed that the incidence of stunting was significantly associated ( $p$ value <0.05) in infants suffering from infectious diseases $(\mathrm{OR}=8.65)$. at 8.65 times the risk of suffering from stunting.

The bivariate analysis of maternal factors showed a significant relationship ( $p$ value $<0.05$ ), namely the variable maternal knowledge $(\mathrm{p}$ value $=0.006) \mathrm{OR}=3.27$ so that it could be interpreted that poor knowledge of mothers had the risk of

Tabel 1. Bivariate analysis of risk factors with stunting in children 2-5 years

\begin{tabular}{llcccc}
\hline \multicolumn{1}{c}{ Child Factor } & \multicolumn{1}{c}{ Category } & Case (\%) & Control (\%) & Value p & OR \\
\hline History of birth weight & $<2,500$ grams & 10 & 0 & 0,03 & 2,13 \\
\multirow{2}{*}{ Long history of length birth } & $>2,500$ grams & 90 & 100 & & \\
& Less $(<48 \mathrm{~cm})$ & 72 & 60 & 1,000 & 1,02 \\
Breastfeeding & Good $(>48 \mathrm{~cm})$ & 28 & 40 & & \\
\multirow{4}{*}{ Infectious disease } & not good & 59 & 56 & 0,54 & 1,41 \\
& good & 41 & 44 & & \\
& often get sick & 80 & 36 & 0,000 & 8,65 \\
& not often get sick & 20 & 64 & & \\
\hline
\end{tabular}

Table 2. Relationship between maternal factors and stunting in children 2-5 years

\begin{tabular}{llcccc}
\hline \multicolumn{1}{c}{ Mother Factor } & \multicolumn{1}{c}{ Category } & Case (\%) Control (\%) & Value p & OR \\
\hline Mother's knowledge & Less & 41 & 26 & 0,006 & 3,27 \\
\multirow{3}{*}{ Mother's height } & Well & 59 & 74 & & \\
\multirow{2}{*}{ Mother's education } & Less $(<150 \mathrm{~cm})$ & 32 & 38 & 0,065 & 3,03 \\
& Normal $(\geq 150 \mathrm{~cm})$ & 68 & 62 & & \\
& Basic & 73 & 49 & 0.014 & 3,19 \\
& Medium and high & 27 & 51 & & \\
\hline
\end{tabular}


increasing 3.27 times the incidence of stunting. compared with good maternal knowledge (Table 2). The environmental factors studied were found to have a significant relationship ( $\mathrm{p}$ value $<0.05)$ with the incidence of under-five stunting, namely father's education, mother's education, family income, food availability in the family and environmental sanitation.

Based on the OR variable which has a significant relationship with stunting, it can be interpreted that mothers with basic education are able to increase 3.19 times greater. A low family income was able to increase 3,820 times as much, and a low sanitation family environment was able to increase 8.4 times more to produce stunted children (Table 3 ). The variables that have a $p$ value $<0.05$ from the results of the bivariate analysis are variables that are included in the multivariate analysis, namely variables of LBW history

Table 3. Relationship between environmental factors and stunting in children 2-5 years

\begin{tabular}{|c|c|c|c|c|c|}
\hline Mother Factor & Category & Case (\%) & Control (\%) & Value $p$ & $\mathbf{O R}$ \\
\hline \multirow[t]{2}{*}{ Environment sanitation } & Not good & 67 & 21 & 0,000 & 8,400 \\
\hline & good & 33 & 79 & & \\
\hline \multirow[t]{2}{*}{ Family income } & $\begin{array}{l}\text { Less than the regional } \\
\text { minimun }\end{array}$ & 57 & 28 & 0,002 & 3,820 \\
\hline & $\begin{array}{l}\text { More or the same as the } \\
\text { regional minimum }\end{array}$ & 43 & 72 & & \\
\hline
\end{tabular}

Table 4. The Most Influential Factors on Stunting

\begin{tabular}{lcccl}
\hline \multicolumn{1}{c}{ Independent Variable } & Constant & OR & 95\% CI & Value p \\
\hline Environment sanitation & 1,73 & 6,40 & $2,01-20.37$ & 0,002 \\
History of Infectious Disease & 2,31 & 8,31 & $2,81-24,10$ & 0,000 \\
\hline
\end{tabular}

analysis, namely variables of LBW history, history of infectious diseases, maternal education, environmental sanitation and family income. The results of multivariate analysis with logistic regression are shown in the table 4.

Based on Table 4, the results of multivariate analysis between risk factors for the incidence of stunting, obtained two variables that show significant risk factors ( $p$ value $<0.05$ ). The two risk factors are infectious diseases and environmental sanitation. The most dominant variable associated with the incidence of stunting was infectious diseases with the greatest OR value, namely 8.31 , meaning that children who often suffer from infectious diseases are at 8.31 times greater risk of stunting than healthy children.

\section{Discussion}

All of the factors studied, infectious disease factors showed the greatest value as a risk factor for the incidence of stunting in children under five years of age. In line with the 1990 UNICEF conceptual framework, one of the direct causes of nutritional problems is infectious diseases. $^{16}$

This is in line with Cherkley's research, 19 which states that linear growth disorders (stunting) often occur in poor children under five in Peru with an average child aged 24 months high. stature is 2.5 centimeters shorter than international standards and diarrheal disease is significantly associated with stunting during childhood. In the research of Tanziha and Kusriadi, $^{20}$ that infectious diseases are associated with the incidence of stunting in infants in West Nusa Tenggara. In this study, the most common infectious diseases among children under 
five were respiratory infection and diarrhea $(43.0 \%)$. More stunted children are more likely to suffer from this infectious disease with a longer duration of time. Also more likely to experience sequelae (sequels) due to common infections that will weaken the physical condition of the child. An environmental factor at risk for the incidence of stunting in toddlers is environmental sanitation, this is in line with the research of Van der Hoek, ${ }^{21}$ which states that children those from families who have clean water facilities have a lower prevalence of diarrhea and stunting than children from families without clean water facilities and ownership of a latrine. In this study, the risk of stunting under five who lived with poor environmental sanitation was higher than with good sanitation. This happens because most of the places where toddlers live do not meet the requirements of a healthy house, lack of ventilation and lighting, there are no closed and watertight garbage dumps, do not have family latrines, and this is supported by the relatively low economic conditions of the family.

Multivariate analysis shows parental education is not a risk factor for stunting in children under five because even though more than half $(59 \%)$ of mothers have good knowledge, it is not followed by attitudes, skills and willingness and practices that lead to changes in the improvement of toddler nutrition. In Saaka's research, ${ }^{23}$ which states that mothers with higher education have a good relationship with knowledge about child development. In this study, most of the mother's education, including basic education and working as farmers / farm laborers and entrepreneurs with relatively low income, had an impact on the nutritional status of children. In Anindita's research, states that an adequate level of income does not necessarily guarantee the nutritional status of toddlers because the income level is not necessarily allocated enough for food needs. The factors of education, family income, and maternal knowledge also determine the ability of the family to apply knowledge, resources, and behavior patterns to promote and improve health status and overcome environmental problems.

In this study also, it showed that children under five with low birth weight were stunted as much as $10 \%$, while in the control group none of the infants had a history of low birth weight babies. This is in accordance with research conducted by Akombi (2017) which states that toddlers who are born with low birth weight are significantly more related to suffering from stunting. ${ }^{12}$ Another study also states that babies born weighing less than 2500 grams will experience obstacles in growth and development and possible decline in intellectual function and more susceptible to infection and hypothermia.

\section{CONCLUSION}

This study shows three factors that together influence the stunting of children aged six to 36 months, namely infectious diseases, food availability and environmental sanitation, and the most dominant infectious diseases are acute respiratory infection and diarrhea.

\section{SUGGESTION}

To control stunting in toddlers, it is necessary to increase family empowerment related to the prevention of infectious diseases through improving dietary and health care patterns and improving environmental sanitation.

\section{REFERENCES}

1. Supariasa. Penilaian Status Gizi. Jakarta: Buku Kedokteran EGC; 2011.

2. Kemenkes. Riset Kesehatan Dasar. 2018.

3. Dinas Kesehatan Jawa Timur. Profil Kesehatan Jawa Timur. 2018.

4. Dinas Kesehatan Kabupaten Malang. Profil Kesehatan Kabupaten Malang. 2018. 
5. Natalina, Rini. Pengaruh Faktor Maternal Dan Pelayanan Antenatal Care (Anc) Terhadap Kejadian Bayi Berat Lahir Rendah (Bblr) Tahun 2020. Wawasan Kesehatan : Jurnal Ilmiah Kesehatan vol 6 nomer 3

6. Akombi, B.J., Agho, K.E., ... Renzaho A. Stunting and severe stunting among children under-5 years in Nigeria: A multilevel analysis. BMC Pediatr. 2017;

7. Haile, D., Azage, M., Mola, T., \& Rainey R. Exploring spatial variations and factors associated with childhood stunting in Ethiopia: spatial and multilevel analysis. BMC Pediatr. 2016;

8. Ali, Zakari, Saaka Mahama, Adams Abdul-Ganiyu, Kamwininaang Stephen $\mathrm{K}$ AA-R. The effect of maternal and child factors on stunting, wasting and underweight among preschool children in Northern Ghana. BMC Nutr. 2017;

9. Tiwari, Rina, Ausman Lynne M AKE. Determinants of stunting and severe stunting among under-fives: evidence from the 2011 Nepal Demographic and Health Survey.Nepal. BMC Pediatr. 2014;

10. World Health Organization. World Health Statistics 2012. Department of Nutrition for Health and Development. 2012.

11. World Health Organization. Childhoold Stunting: Challenges and Opportunities. Department of Nutrition for Health and Development. 2013.

12. RI KK. Pusat Data dan Informasi 2018. Kemenkes RI. 2018.

13. Kemenkes RI. Infodatin Pusat Data dan Informasi Kementerian Kesehatan Republik Indonesia. Kementrian Kesehatan Republik Indonesia. 2015.

14. Putri. Hubungan Tingkat Pendidikan Ibu, Pendapatan Keluarga, Kecukupan Protein dan Zinc dengan Stunting (Pendek) pada Bal- ita Usia 6- 35
Bulan di Kecamatan Tembalang Kota Semarang. J Kesehat Masy (JKM) Gizi Kesehat Masy Fak Kes- ehatan Masyarakat, Univ Diponegoro. 2012;1(2):617-626.

15. Sattu M. Karakteristik Balita Stunting Di Wilayah Kerja Puskesmas Teku Kecamatan Balantak Utara Kabupaten Banggai. Online J Nat Sci [Internet]. 2014;3(December):239-47. Available from:

file $/ / / \mathrm{C}: / U s e r s / A S U S / D o c u m e n t s / S E$

MESTER 3/komp/3328-10355-1PB.pdf\%0Ahttp://jurnal.untad.ac.id/jur nal/index.php/ejurnalfmipa/article/vie $\mathrm{w} / 3328$

16. Najahah I, Adhi KT, Pinatih GNI. Faktor risiko balita stunting usia 12-36 bulan di Puskesmas Dasan Agung, Mataram, Provinsi Nusa Tenggara Barat. Public Heal Prev Med Arch. 2013;1(2):103.

17. Putri S. Hubungan Cara Konsumsi Tablet Fe Dengan Kejadian Anemia Pada Ibu Hamil Trimester Ii Dan Iii Di Puskesmas Tegalrejo Yogyakarta Tahun2015. 2015;

18. Rosita NA. Peran Dukungan Orang Tua Faktor Yang Paling Berpengaruh Terhadap Pemberian Asi Ekslusif. Unnes J Public Heal. 2016;5(4):355.

19. Taufiqurrohman. Defisiensi Vitamin A dan Zinc Sebagai Faktor Risiko TerjadinyaStunting Pada Balita Di Nusa Tenggara Barat. J Media Penelitan dan Pengembang Kesehat. 2019;21(2):141-52.

20. Lampung B, Nugroho A, Susanto H, Kartasurya MI. Pengaruh mikronutrien taburia terhadap perkembangan motorik anak usia 24-48 bulan yang stunting ( Studi di Tanjungkarang Barat. J Gizi Indones. 2016;

21. Rahim. Faktor Risiko Underweight Balita Umur 7-59 Bulan. KESMAS - J Kesehat Masy. 2014;9(2):115-21. 
22. Septiana. Hubungan Antara Pola Pemberian Makanan Pendamping Asi ( Mp-Asi ) Dan Status Gizi Balita Usia 6-24 Bulan. 2010;118-24.

23. Doloksaribu TH, Syarief H, Marliyati SA. Pertumbuhan Bayi Dan Pemberian Asi Eksklusif Oleh Ibu
Penerima Konseling Menyusui Dan Makanan Tambahan Torbangun. J Gizi dan Pangan. 2016;10(2):77-84.

24. Alim A, Thaha R, Citrakesumasari. Evaluating Ground Provision Taburia In The City Of Makassar In 2011. 2011;1-16. 